\title{
$D B H$ gene variants that cause low plasma dopamine $\beta$ hydroxylase with or without a severe orthostatic syndrome
}

\author{
J Deinum, G C H Steenbergen-Spanjers, M Jansen, F Boomsma, J W M Lenders, F J van Iftersum, \\ N Hück, L P van den Heuvel, R A Wevers
}

J Med Genet 2004;41:e38 (http://www.jmedgenet.com/cgi/content/full/41/4/e38). doi: 10.1136/jmg.2003.009282

$\mathrm{T}$ he enzyme dopamine $\beta$ hydroxylase (EC 1.14.17.1, MIM 223360 ) is a monooxygenase that catalyses the conversion of dopamine to norepinephrine. It requires copper as a cofactor and uses oxygen and ascorbate as cosubstrates. ${ }^{1}$ Dopamine $\beta$ hydroxylase is localised within the soluble and membrane fractions of secretory vesicles of neurones of the central nervous system that produce epinephrine and norepinephrine, sympathetic ganglia, and cells of the adrenal medulla. ${ }^{2-4}$ The soluble form of the enzyme is secreted into the circulation, together with norepinephrine, from nerve terminals. ${ }^{56}$ The major form of this glycosylated enzyme seems to be a tetramer of $290 \mathrm{kD}^{7}$ Dopamine $\beta$ hydroxylase continues to receive much attention because of its importance in the synthesis of catecholamines and, hence, its possible involvement in psychiatric disorders such as depression.

Concentrations of dopamine $\beta$ hydroxylase in blood vary considerably in the general population, but intra-individual variation is low. ${ }^{8}$ Some $4 \%$ of the population have nearly undetectable plasma concentrations, with normal concentrations of norepinephrine and epinephrine. ${ }^{9}$ Extremely low plasma concentrations of dopamine $\beta$ hydroxylase seems to be inherited monogenetically by an autosomal codominant mechanism. Recently, Zabetian et al. provided strong arguments that an allelic variant in the $5^{\prime}$ flanking region $(-1021)$ is the major quantitative trait locus that determines plasma concentrations of dopamine $\beta$ hydroxylase. ${ }^{10}$ Absence of dopamine $\beta$ hydroxylase also has been described in conjunction with nearly undetectable concentrations of norepinephrine and epinephrine, hugely elevated concentrations of dopamine, and a syndrome of sympathetic failure. ${ }^{11-13}$ This is compatible with defective conversion of dopamine to norepinephrine by dopamine $\beta$ hydroxylase, and it therefore can be designated as dopamine $\beta$ hydroxylase deficiency syndrome. This phenotype seems to be transmitted as a recessive trait, and it can be treated successfully by administration of L-threo-3,4-dihydroxyphenylserine, which can be decarboxylated by aromatic-L-amino acid decarboxylase into norepinephrine. ${ }^{14}$ Recently, two mutations associated with dopamine $\beta$ hydroxylase deficiency syndrome were identified in the $D B H$ gene. ${ }^{15}$ We aimed to identify mutations in $D B H$ that cause dopamine $\beta$ hydroxylase deficiency syndrome in four families with members who had an orthostatic syndrome with undetectable concentrations of dopamine $\beta$ hydroxylase and high concentrations of dopamine. We related our findings to the -1021 allelic variant of the $D B H$ gene and to low plasma concentrations of dopamine $\beta$ hydroxylase in these families and in healthy people.

\section{MATERIALS AND METHODS}

Genomic DNA was extracted from leucocytes by standard methods. Sequence analysis was performed with polymerase chain reaction (PCR) and direct cycle sequencing. Cycle

\section{Key points}

- Dopamine $\beta$ hydroxylase deficiency syndrome is defined as a severe orthostatic hypotension with high plasma concentrations of dopamine and (near) absent plasma concentrations of norepinephrine and epinephrine.

- In all four families that we identified with the syndrome, we found several different mutations in the DBH gene that led to truncated proteins or an altered sequence in highly conserved regions. One of the mutations, a splice site variant, was present in three of our families and has also been described in the United States. Whether these families have a common ancestor or whether the mutation is caused by a specific DNA sequence motif that plays a role in the breaking and joining of DNA is uncertain.

- Absence of plasma dopamine $\beta$ hydroxylase occurs not only in patients who have dopamine $\beta$ hydroxylase deficiency syndrome but also in $4 \%$ of the normal population. This trait cosegregates with a dimorphic marker in the promoter region of the $D B H$ gene. When plasma concentrations of dopamine $\beta$ hydroxylase are studied, the DBH genotype should be taken into account.

sequencing was carried out by the Taq Dye-deoxy Terminator method with the ABI Prism dRhodamine Terminator Cycle Sequencing Ready Reaction Kit (PE Applied Biosystems, Foster City, CA, USA) on an ABI DNA 377 Sequencer with standard procedures. Primers were from Life Technologies (Breda, Netherlands) and were designed to allow analyses of complete exons, including intron boundaries, according to the publicly available genomic sequence of chromosome 9q34 (Genbank accession number AC 000404). The primer sequences and PCR protocols are available upon request. To confirm the mutations, we performed restriction analyses of appropriate PCR fragments with Ita I (Boehringer, Mannheim, Germany), Scr Fl (New England Biolabs, Leusden, Netherlands), or HhaI (Invitrogen, Breda, Netherlands) according to the manufacturer's recommendations.

We obtained plasma and DNA data from index patients with orthostatic syndrome and absent dopamine $\beta$ hydroxylase in plasma and from their parents and at least one sibling. For catecholamine determination, participants received an intravenous catheter and rested in the supine position for at least 30 minutes before blood was taken $(10 \mathrm{ml}$ in heparinised tubes that contained $10 \mathrm{mg}$ glutathione). Plasma concentrations of epinephrine, norepinephrine, and dopamine were measured after derivatisation and separation 
by high performance liquid chromatography. ${ }^{16}$ Plasma concentrations of dopamine $\beta$ hydroxylase were quantified by the enzyme's ability to convert tyramine into octopamine. ${ }^{17}$

We recruited 49 consecutive healthy blood donors to determine the genotypes at the -1021 and IVS 4+601 loci and to measure plasma concentrations of dopamine $\beta$ hydroxylase in unselected people. All participants gave their consent for this study.

We used the HWSIM package (http://krunch.med.yale.edu/ hwsim/) to assess the Hardy-Weinberg equilibrium. Statistical analysis was performed with SPSS (version 9.0 for Windows). We used the PredictProtein Server for sequence comparison (http://www.embl-heidelberg.de/predictprotein/).

\section{RESULTS}

Figure 1 shows the family trees of the four families with index patients with undetectable concentrations of dopamine $\beta$ hydroxylase and orthostatic syndrome. Clinical characteristics of probands from families A and B have been described elsewhere. ${ }^{12}{ }^{13}$ Briefly, the index patients from families A and $\mathrm{B}$ had symptoms from an early age. The most obvious symptom in patients A2.2, B2.1, and D2.2 was orthostatic syndrome with sympathetic failure. Patient C2.2 presented with unexplained mild anaemia and postural dizziness at age 30 years. Her history was remarkable for a propensity to diarrhoea and exercise intolerance during childhood. Orthostatic hypotension eventually was diagnosed. Patient D (participant 2.2 in fig 1) presented with vertigo because of orthostatic hypotension at age 20 years. Her symptoms resolved during pregnancy; attempts at lactation failed. At 40 years of age, one year before dopamine $\beta$ hydroxylase deficiency syndrome was diagnosed, she had to leave her job because of severe postural hypotension. All patients had extremely low plasma concentrations of norepinephrine and epinephrine and increased or high normal concentrations of dopamine. The parasympathic reflex arch was intact. Other characteristics included ptosis of eyelids, weak facial musculature, high palate, and sluggish deep tendon reflexes. All patients had normal intellectual capacities. In family A, two other members had undetectable concentrations of dopamine $\beta$ hydroxylase, although they did not have orthostatic syndrome or abnormal plasma concentrations of catecholamines (fig 1 ; table 1 ). In family $\mathrm{B}$, the phenotypically normal father had nearly undetectable concentrations of dopamine $\beta$ hydroxylase. Participant 2.2 of family A, who was phenotypically normal and had normal concentrations of catecholamine, was not available for genetic studies. In family D, the mother and two siblings of the proband had undetectable concentrations of dopamine $\beta$ hydroxylase. Participant D2.5 reported orthostatic complaints. Her brother (D2.1) had no spontaneous complaints, but he had a severe decrease in blood pressure during orthostatic challenge. Participants D2.1 and D2.5 had high concentrations of dopamine and very low concentrations of epinephrine and norepinephrine.

By direct sequencing, we identified four mutations in the $D B H$ gene. In family $\mathrm{A}$, the index patient was homozygous for a mutation of the $5^{\prime}$ splice site in the first intron $($ IVS $1+2 \mathrm{~T}>\mathrm{C})$. This mutation predicts abnormal splicing and hence an afunctional protein. It creates an ItaI restriction site, which we used to screen 100 control alleles. The sister and parents of patient A were heterozygous for this mutation. In family $\mathrm{B}$, the index patient was a compound heterozygote for this same splice site mutation and a deletion of an adenine at position 575 in exon 3 (c.575delA), which caused a frameshift and premature stop codon at c.817 in exon 4 and generated a truncated protein of 272 amino acids instead of 603, with glycine as the first affected amino acid (G192fs). This mutation created an Scr FI restriction site. Patient C2.2 was homozygous for a mutation in the fourth exon (764
$\mathrm{G}>\mathrm{T}$ ), which led to substitution of cysteine by phenylalanine $(\mathrm{C} 255 \mathrm{~F})$. This altered a sequence (HHMEVFQC $>\mathrm{F})$ that is specific to copper type II ascorbate dependent monooxygenases and is highly conserved in various species (fig 2). This mutation abolishes a HhaI restriction site. In the index patient of family D, the splice site variant of families A and B was present, and in the other allele, a mutation in exon 11 was present $(1625 \mathrm{~A}>\mathrm{G})$, which led to a substitution of tyrosine by cysteine (Y542C). This mutation is in a highly conserved region of an $\alpha$ helix (fig 2). Mutation 1625A $>$ G creates an ItaI restriction site. None of the four mutations was present in 100 control alleles.

In family $\mathrm{D}$, we also found a variant at nucleotide 560 in exon $3(560 \mathrm{~A}>\mathrm{G})$, cis to $1625 \mathrm{~A}>\mathrm{G}$ of exon 11 , which led to a substitution of asparagine by serine (N187S). As this variant was also present on one allele in three control participants, and this region is not conserved among various species (not shown), we considered this a polymorphism rather than a causative mutation.

We also assessed the genotype for an allelic variant in the $5^{\prime}$ region of the gene at position $-1021(C>T)$ and a variant in intron 4 (IVS4+601 $\mathrm{T}>\mathrm{C}$ ) in the four families and 49 control participants. The $\mathrm{T}$ allele at position -1021 , which is associated with absence of dopamine $\beta$ hydroxylase in plasma, was present in families A, B, and D (table 1). Family members A1.2, A2.3, and D1.2 were homozygous for the $-1021 \mathrm{~T}$ allele. Participant Bl.1, who had -1021T in his normal $D B H$ allele and $-1021 \mathrm{C}$ in the allele that contained the c.575delA mutation, also had extremely low plasma concentrations of dopamine $\beta$ hydroxylase. All four individuals carried only one of the mutated $D B H$ alleles associated with dopamine $\beta$ hydroxylase deficiency syndrome but had no clinical syndrome of dopamine $\beta$ hydroxylase deficiency.

The control group was in Hardy-Weinberg equilibrium at the -1021 locus. Figure 3 shows the concentrations of plasma dopamine $\beta$ hydroxylase in the three genotype groups among healthy blood donors. Our data confirm that patients with the CC genotype had the highest concentrations of dopamine $\beta$ hydroxylase, those with the TT genotype the lowest concentrations, and those with the CT genotype intermediate concentrations (ANOVA, $\mathrm{p}<0.0001$ ). The median activity of dopamine $\beta$ hydroxylase in the CT group was $45.3 \%$ of that in the CC group, which suggested a $90.6 \%$ reduction of plasma concentration of dopamine $\beta$ hydroxylase in patients with the TT phenotype (fig 3). The -1021 genotype explains $50 \%$ of the variance of plasma concentrations of dopamine $\beta$ hydroxylase. Addition of the IVS4+601T $>C$ genotype, which was weakly associated with plasma concentrations of dopamine $\beta$ hydroxylase (data not shown), increased the predictability of plasma concentrations of dopamine $\beta$ hydroxylase by $3 \%$, but the difference with the model that incorporated the -1021 genotype only was not significant $(\mathrm{p}=0.089)$.

\section{DISCUSSION}

In this study, we provided further evidence that dopamine $\beta$ hydroxylase deficiency syndrome has a genetic origin by identifying four mutations that are associated uniquely with orthostatic syndrome, high plasma concentrations of dopamine, near undetectable concentration of norepinephrine and epinephrine, and lack of dopamine $\beta$ hydroxylase in the plasma in the conditions that define dopamine $\beta$ hydroxylase deficiency syndrome.

In a previous paper, Kim et al. described in two patients with dopamine $\beta$ hydroxylase deficiency syndrome the splice site mutation that we found in families $\mathrm{A}, \mathrm{B}$, and $\mathrm{D}^{15}$; these patients were described previously by Biaggioni et al. ${ }^{18}$ Apparently, this seems not to be an isolated mutation in 
Family A

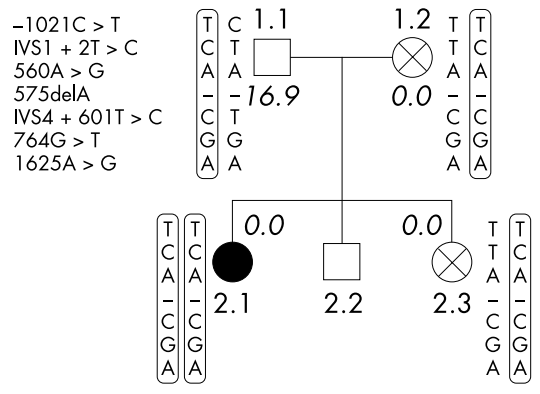

Family C

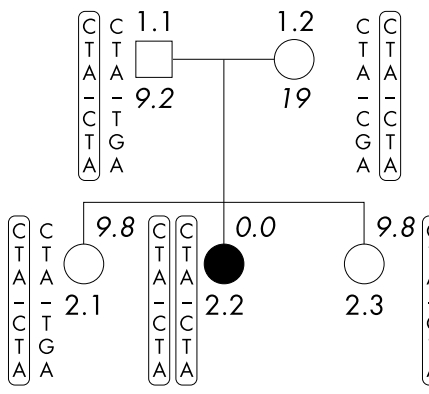

Family B

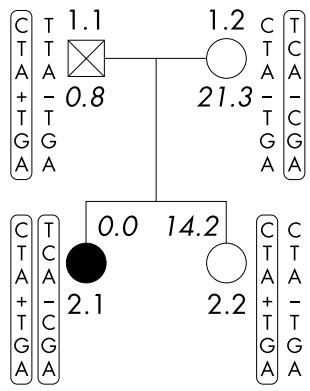

Family D

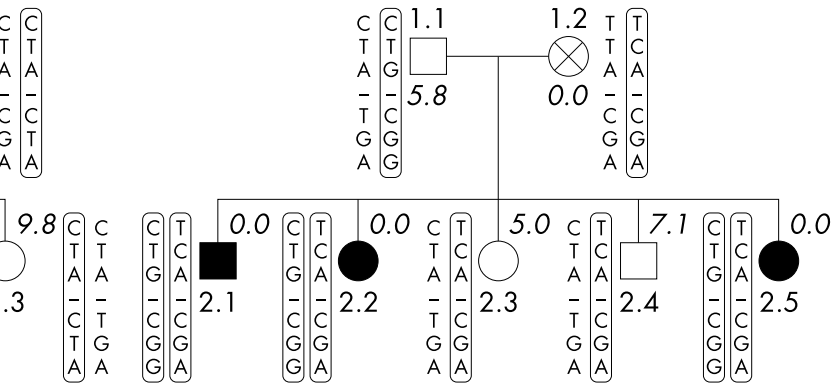

Figure 1 Family trees of patients with dopamine $\beta$ hydroxylase deficiency syndrome. man with syndrome; $\square$ man without syndrome; $\bullet$ woman with syndrome; $\bigcirc$ woman without syndrome; $\times$ dopamine $\beta$ hydroxylase absent in plasma but participant did not have orthostatic syndrome.

Haplotypes of the $D B H$ gene, determined from inheritance patterns, are given next to the symbols. The order of variant loci of the $D B H$ gene from $5^{\prime}$ to $3^{\prime}$ is given in the upper left of the figure in descending order. Haplotypes that contained mutations associated with dopamine $\beta$ hydroxylase deficiency syndrome are boxed. Numbers in ifalics are plasma concentrations of dopamine $\beta$ hydroxylase in U/l. Participant A2.2 was not available for genetic analysis.

only one family, although the frequency of this allele is very low. ${ }^{19}$ Specific DNA sequence motifs are known to play a role in breakage and rejoining of DNA. Some of these have been shown to be overrepresented in the region $10 \mathrm{bp}$ on either side of mutations. They therefore may play a role in the occurrence of more common mutations. Among such motifs are TTT, GAA, TTG, CTT, and TTTG sequences. ${ }^{20}$ A TTTG tetranucleotide is located in close vicinity of the IVSI+2T $>$ C mutation. Although this may explain a multiple occurrence of this mutation, the very low frequency of the mutation in a

Table 1 Clinical and biochemical characteristics and genetic variation of the DBH gene in four families with dopamine $\beta$ hydroxylase deficiency syndrome ${ }^{*}$

\begin{tabular}{|c|c|c|c|c|c|c|c|}
\hline \multirow[b]{2}{*}{ Participant } & \multirow[b]{2}{*}{ Orthostasis } & \multicolumn{4}{|l|}{ Plasma levels† } & \multirow{2}{*}{$\begin{array}{l}\text { Mutation associated with } \\
\text { dopamine } \beta \text { hydroxylase } \\
\text { deficiency syndrome }\end{array}$} & \multirow[b]{2}{*}{$\begin{array}{l}-1021 \\
\text { genotype }\end{array}$} \\
\hline & & $\begin{array}{l}\text { Norepinephrine } \\
\text { (pg/ml) }\end{array}$ & $\begin{array}{l}\text { Epinephrine } \\
\text { (pg/ml) }\end{array}$ & $\begin{array}{l}\text { Dopamine } \\
\text { (pg/ml) }\end{array}$ & $\begin{array}{l}\text { Dopamine } \\
\beta \text { hydroxylase (U/I) }\end{array}$ & & \\
\hline $\begin{array}{l}\text { A1.1 } \\
\text { A.1.2 }\end{array}$ & $\begin{array}{l}\text { No } \\
\text { No }\end{array}$ & $\begin{array}{l}720 \\
439\end{array}$ & $\begin{array}{l}121 \\
32\end{array}$ & $\begin{array}{l}60 \\
45\end{array}$ & $\begin{array}{l}16.9 \\
0\end{array}$ & $\begin{array}{l}\text { Heterozygous IVSI+2T }>C \\
\text { Heterozygous IVSI+2T }>C\end{array}$ & $\begin{array}{l}\mathrm{TC} \\
\mathrm{T}\end{array}$ \\
\hline A2.1 & Yes & 0 & 0 & 480 & 0 & Homozygous IVS1+2T>C & $\pi$ \\
\hline $\begin{array}{l}\mathrm{A} 2.2 \\
\mathrm{~A} 2.3 \\
\mathrm{~B} 1.1 \\
\mathrm{~B} 1.2\end{array}$ & $\begin{array}{l}\text { No } \\
\text { No } \\
\text { No } \\
\text { No }\end{array}$ & $\begin{array}{l}602 \\
184 \\
117 \\
244\end{array}$ & $\begin{array}{l}428 \\
112 \\
19 \\
91\end{array}$ & $\begin{array}{l}68 \\
27 \\
31 \\
23\end{array}$ & $\begin{array}{l}19.6 \\
0 \\
0.8 \\
21.3\end{array}$ & $\begin{array}{l}\text { ND } \\
\text { Heterozygous IVS } 1+2 T>C \\
\text { Heterozygous c. } 575 \text { delA } \\
\text { Heterozygous IVS } 1+2 T>C\end{array}$ & $\begin{array}{l}\mathrm{ND} \\
\mathrm{T} \\
\mathrm{TC} \\
\mathrm{TC}\end{array}$ \\
\hline B2.1 & Yes & 0 & 0 & 250 & 0 & $\mathrm{IVS} 1+2 \mathrm{~T}>\mathrm{C} / \mathrm{c} .575 \mathrm{del} \mathrm{A}$ & TC \\
\hline $\begin{array}{l}\mathrm{B} 2.2 \\
\mathrm{C} 1.1 \\
\mathrm{C} 1.2 \\
\mathrm{C} 2.1\end{array}$ & $\begin{array}{l}\text { No } \\
\text { No } \\
\text { No } \\
\text { No }\end{array}$ & $\begin{array}{l}195 \\
231 \\
187 \\
231\end{array}$ & $\begin{array}{l}78 \\
18 \\
45 \\
11\end{array}$ & $\begin{array}{l}12 \\
5 \\
4 \\
44\end{array}$ & $\begin{array}{l}14.2 \\
9.2 \\
19 \\
9.8\end{array}$ & $\begin{array}{l}\text { Heterozygous c.575delA } \\
\text { Heterozygous } 764 G>T \\
\text { Heterozygous } 764 G>T \\
\text { Heterozygous } 764 G>T\end{array}$ & $\begin{array}{l}\mathrm{CC} \\
\mathrm{CC} \\
\mathrm{CC} \\
\mathrm{CC}\end{array}$ \\
\hline $\mathrm{C} 2.2$ & Yes & 0 & 7 & 77 & 0 & Homozygous 764G $>\mathrm{T}$ & $\mathrm{CC}$ \\
\hline $\begin{array}{l}\text { C2.3 } \\
\text { D1.1 } \\
\text { D1.2 }\end{array}$ & $\begin{array}{l}\text { No } \\
\text { No } \\
\text { No }\end{array}$ & $\begin{array}{l}131 \\
379 \\
430 \\
\end{array}$ & $\begin{array}{l}19 \\
119 \\
59\end{array}$ & $\begin{array}{l}3 \\
20 \\
14\end{array}$ & $\begin{array}{l}9.8 \\
5.8 \\
0\end{array}$ & $\begin{array}{l}\text { Heterozygous } 764 \mathrm{G}>\mathrm{T} \\
\text { Heterozygous } 1625 \mathrm{~A}>\mathrm{G} \\
\text { Heterozygous IVS1+2T>C }\end{array}$ & $\begin{array}{l}\mathrm{CC} \\
\mathrm{CC} \\
\pi\end{array}$ \\
\hline D2.1 & Yes & 20 & 72 & 205 & 0 & $\mathrm{IVS} 1+2 \mathrm{~T}>\mathrm{C} / 1625 \mathrm{~A}>\mathrm{G}$ & $\mathrm{TC}$ \\
\hline D2.2 & Yes & 0 & 10 & 51 & 0 & $\mathrm{IVS} 1+2 \mathrm{~T}>\mathrm{C} / 1625 \mathrm{~A}>\mathrm{G}$ & $\mathrm{TC}$ \\
\hline $\begin{array}{l}\text { D2.3 } \\
\text { D2.4 }\end{array}$ & $\begin{array}{l}\text { No } \\
\text { No }\end{array}$ & $\begin{array}{l}235 \\
293\end{array}$ & $\begin{array}{l}23 \\
35\end{array}$ & $\begin{array}{l}10 \\
10\end{array}$ & $\begin{array}{l}5 \\
7.1 \\
\end{array}$ & $\begin{array}{l}\text { Heterozygous IVSI+2T }>C \\
\text { Heterozygous IVS I+2T }>C\end{array}$ & $\begin{array}{l}\text { TC } \\
\text { TC }\end{array}$ \\
\hline D2.5 & Yes & 5 & 0 & 114 & 0 & $I V S 1+2 T>C / 1625 A>G$ & TC \\
\hline
\end{tabular}

ND, not determined; C, C allele; T, T allele.

* Participants with orthostatic hypotension boxed.

† Normal values: $<600 \mathrm{pg} / \mathrm{ml}$ for norepinephrine, $<120 \mathrm{pg} / \mathrm{ml}$ for epinephrine, and $<60 \mathrm{pg} / \mathrm{ml}$ for dopamine. 
A

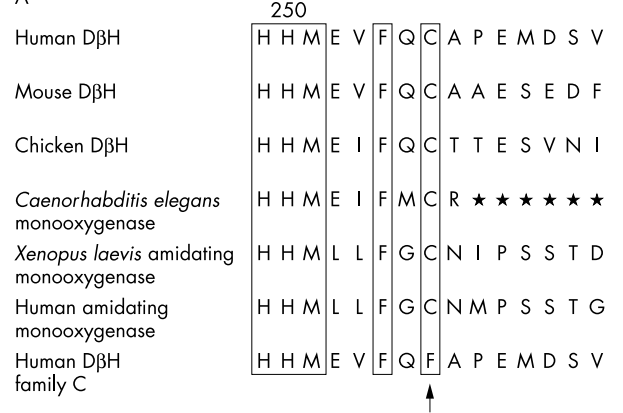

B

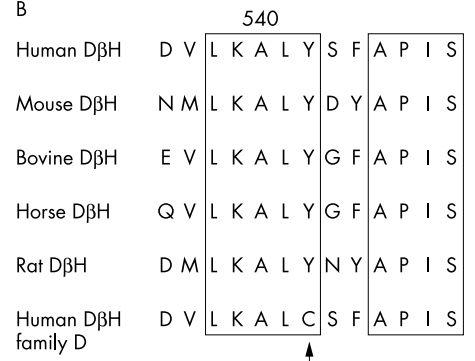

Figure 2 Amino acid sequence of the copper binding regions of two types of monooxygenases (dopamine $\beta$ hydroxylase and peptidylglycine amidating monooxygenase) of different species (A) and amino acid sequence in $D B H$ genes of various species and the $D B H$ allele present in family $D$ and associated with dopamine $\beta$ hydroxylase deficiency syndrome (B). The consensus sequence is boxed. In (A), the mutated amino acid in family $C$ with dopamine $\beta$ hydroxylase deficiency syndrome is indicated by an arrow. In (B), the consensus sequence "LKALY" is part of a conserved $\alpha$ helix and the mutated amino acid is indicated by an arrow.

large control group ${ }^{19}$ and the absence of it in our control group may argue against this mechanism. In view of the identical haplotype of this mutation in all people, we cannot rule out, therefore, that a founder effect may play a role (fig 1). The three marker background haplotype we defined, however, has an expected frequency of 0.1 that does not allow a definitive conclusion. A 12 marker haplotype of the same mutation had a background frequency of $<0.01$, which argues for a shared ancestor. ${ }^{19}$ It would be interesting to genotype our patients for the same markers, especially as one of the patients in the study by Kim et al. was known to be of Dutch descent. ${ }^{15}$

The fact that the index patient from family $\mathrm{A}$ is homozygous for the splice site mutation lends strong support to the notion that this mutation is causative for dopamine $\beta$ hydroxylase deficiency syndrome. This mutation, as well as the c.575delA mutation from family $\mathrm{B}$, results in heavily truncated proteins. The index patient from family $\mathrm{C}$ is unique, in that she is not a compound heterozygote but is homozygous for a mutation that is located in a highly preserved region for copper containing monooxygenases. The index patient from family $\mathrm{D}$ is compound heterozygous for the splice site mutation and a mutation on the trans allele that is located in an $\alpha$ helix. As the latter is also a conserved region, we assume that this region is crucial for normal enzymatic function.

The interesting aspect of our families is that some members of families A, B, and D have (near) absent plasma concentrations of dopamine $\beta$ hydroxylase but no orthostatic syndrome. They are heterozygous for the pathogenic $D B H$ mutations, which may explain a $50 \%$ reduction in dopamine $\beta$ hydroxylase activity. Their very low concentrations of dopamine $\beta$ hydroxylase are explained readily by the presence of thymidine at -1021 of their normal $D B H$ allele. The fact that participants A1.2, A2.3, B1.1, and D1.2 harbour a thymidine at -1021 on their normal $D B H$ allele and have extremely low concentration of dopamine $\beta$ hydroxylase lends further support to the evidence presented by Zabetian et al. that the -1021 site is the major quantitative trait locus of dopamine $\beta$ hydroxylase. ${ }^{10}$ Formal experimental proof, however, still must be obtained.

Our observation again raises the important question of how an allele variant $(-1021)$ in a non-coding region of the gene can cause absence of secretion of a protein to the plasma without causing obvious functional changes. Reduced expression because of altered regulatory elements in linkage desequilibrium with the $-1021 \mathrm{~T}$ allele provides an explanation. This is difficult to reconcile, however, with the normal synthesis of norepinephrine that these people seem to haveunless only extremely small amounts of dopamine $\beta$ hydroxylase are needed to ensure normal synthesis of catecholamines.

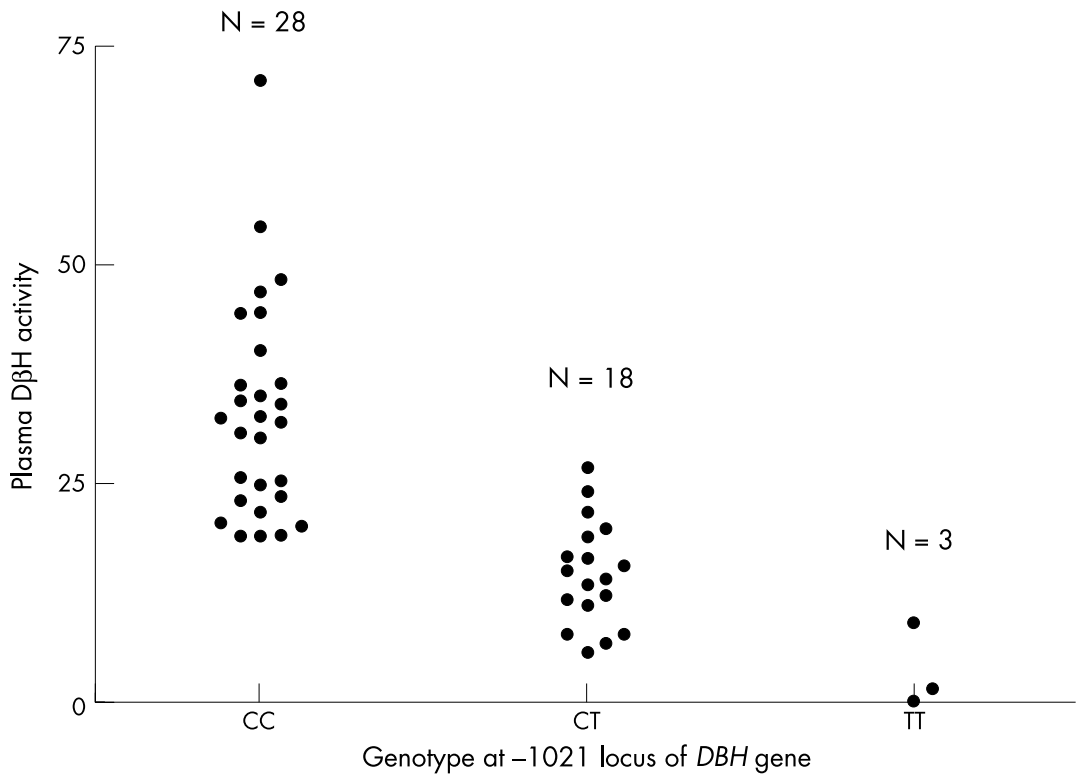

Figure 3 Plasma activity of dopamine $\beta$ hydroxylase (U/I) in 49 controls, by group according to genotype at the -1021 locus. 


\section{Conclusion}

We determined the genetic basis of dopamine $\beta$ hydroxylase deficiency syndrome. Absence of dopamine $\beta$ hydroxylase in plasma, however, seems to be determined in most people by a locus in the $5^{\prime}$ flanking region of the $D B H$ gene, which has few or no functional consequences. In four families, we were able to show that severe orthostatic syndrome in the index cases was derived from truncating, splice site, or missense mutations in the $D B H$ gene. These observations raise interesting issues about the synthesis of norepinephrine and epinephrine. In studies that address plasma concentrations of dopamine $\beta$ hydroxylase, the $D B H$ genotype must be taken into account.

\section{Authors' affiliations}

J Deinum, J W M Lenders, Department of Medicine, University Medical Center Nijmegen St Radboud, Geert Grooteplein 8, 6525 GA

Nijmegen, Netherlands

G C H Steenbergen-Spanjers, M Jansen, N Hück, L P van den Heuvel,

R A Wevers, Laboratory of Pediatrics and Neurology, University Medical Center Nijmegen St Radboud, Reinier Postlaan 4, 6500 HB Nijmegen, Netherlands

F Boomsma, Department of Medicine, Erasmus University Medical Center Rotterdam, Room L 276, Dr. Molewaterplein 40, 3015 GD Rotterdam, Netherlands

F J van Ittersum, Department of Nephrology, Vrije Universiteit Medical Center, Amsterdam, De Boelelaan 11171081 HV Amsterdam,

Netherlands

Correspondence to: Dr J Deinum, Department of Medicine, University Medical Center Niimegen St Radboud, Geert Grooteplein 8, 6525 GA Niimegen, Netherlands; e-mail j.deinum@aig.umen.nl

Conflicts of interest: none declared.

Received 7 April 2003

Accepted for publication 8 September 2003

\section{REFERENCES}

1 Rush RA, Geffen LB. Dopamine beta-hydroxylase in health and disease. Crit Rev Clin Lab Sci 1980:12:241-77.

2 Oka M, Kajikawa K, Ohuchi T, Yoshida H, Imaizumi R. Distribution of dopamine-beta-hydroxylase in subcellular fractions of adrenal medulla. Life Sci 1967;6:461-5.

3 Teitelman G, Baker H, Joh TH, Reis DJ. Appearance of catecholaminesynthesizing enzymes during development of rat sympathetic nervous system: possible role of tissue environment. Proc Natl Acad Sci USA 1979:76:509-13.
4 Kemper CM O'Connor DT, Westlund KN Immunocytochemical localization of dopamine-beta-hydroxylase in neurons of the human brain stem. Neuroscience 1987;23:981-9.

5 Viveros $\mathrm{OH}$, Arqueros L, Connett RJ, Kirshner N. Mechanism of secretion from the adrenal medulla. 3. Studies of dopamine beta-hydroxylase as a marker for catecholamine storage vesicle membranes in rabbit adrenal glands. Mol Pharmacol 1969;5:60-8.

6 Weinshilboum RM. Serum dopamine beta-hydroxylase. Pharmacol Rev 1978;30:133-66

7 Frigon RP, Stone RA. Human plasma dopamine beta-hydroxylase. Purification and properties. J Biol Chem 1978;253:6780-6.

8 Fahndrich E, Coper H, Christ W, Helmchen H, Muller-Oerlinghausen B, Pietzcker A. Erythrocyte COMT-activity in patients with affective disorders. Acta Psychiatr Scand 1980;61:427-37.

9 Weinshilboum RM, Schorott HG, Raymond FA, Weidman WH, Elveback LR Inheritance of very low serum dopamine-beta-hydroxylase activity. Am J Hum Genet 1975;27:573-85.

10 Zabetian CP, Anderson GM, Buxbaum SG, Elston RC, Ichinose H, Nagatsu T, Kim KS, Kim CH, Malison RT, Gelernter J, Cubells JF. A quantitative-trait analysis of human plasma-dopamine beta-hydroxylase activity: evidence for a major functional polymorphism at the DBH locus. Am J Hum Genet $2001 ; 68: 515-22$

11 Robertson D, Goldberg MR, Onrot J, Hollister AS, Wiley R, Thompson JG Jr, Robertson RM. Isolated failure of autonomic noradrenergic neurotransmission. Evidence for impaired beta-hydroxylation of dopamine. N Engl J Med 1986;314:1494-7.

12 Man in 't Veld AJ, Boomsma F, Moleman P, Schalekamp MA. Congenital dopamine-beta-hydroxylase deficiency. A novel orthostatic syndrome. Lancet 1987; 1:183-8

13 Man in 't Veld A, Boomsma F, Lenders J, vd Meiracker A, Julien C, Tulen J, Moleman P, Thien T, Lamberts S, Schalekamp M. Patients with congenital dopamine beta-hydroxylase deficiency. A lesson in catecholamine physiology. Am J Hypertens 1988;1:231-8.

14 Man in 't Veld AJ, Boomsma F, van den Meiracker AH, Schalekamp MA. Effect of unnatural noradrenaline precursor on sympathetic control and orthostatic hypotension in dopamine-beta-hydroxylase deficiency. Lancet 1987;2:1172-5.

15 Kim CH, Zabetian CP, Cubells JF, Cho S, Biaggioni I, Cohen BM, Robertson D, Kim KS. Mutations in the dopamine beta-hydroxylase gene are associated with human norepinephrine deficiency. Am J Med Genet 2002; 108: 140-7.

16 van der Hoorn FA, Boomsma F, Man in 't Veld AJ, Schalekamp MA Determination of catecholamines in human plasma by high-performance liquid chromatography: comparison between a new method with fluorescence detection and an established method with electrochemical detection. J Chromatogr 1989;487:17-28.

17 Kato T, Kuzuya H, Nagatsu T. A simple and sensitive assay for dopaminebeta-hydroxylase activity by dual-wavelength spectrophotometry. Biochem Med 1974; 10:320-8

18 Biaggioni I, Goldstein DS, Atkinson T, Robertson D. Dopamine $\beta$-hydroxylase deficiency in humans. Neurology 1990:40:370-3.

19 Zabetian CP, Romero R, Robertson D, Sharma S, Padbury JF, Kuivaniemi H, Kim K-S, Kim C-H, Köhnke MD, Kranzler HR, Gelernter J, Cúbells JF. A revised allele frequency estimate and haplotype analysis of the DBH deficiency mutation IVS 1+2T >C in African- and European-Americans. Am J Med Genet 2003; 123A:190-2

20 Cooper DN, Krawczak M, Antonarkis SE. The nature and mechanisms of human gene mutation. In: Scriver CBA, Sly W, Valle D, eds. The metabolic and molecular basis of inherited disease. New York: McGraw Hill, 1995. 